\title{
INOVASI FORMULA PRODUK HAND RUB BERBASIS ALKOHOL SEBAGAI UPAYA EFISIENSI PENGELOLAAN SEDIAAN FARMASI DI RUMAH SAKIT
}

Ahmad Subhan ${ }^{1}$, Wasmen Manalu², Min Rahminiwati ${ }^{3}$, Huda Salahudin Darusman ${ }^{4}$

\author{
${ }^{1}$ Apoteker Farmasi Klinik RSUP Fatmawati Jakarta \\ ${ }^{2}$ Pembimbing 1 dan Ketua prodi IImu Faal dan Khasial Obat IPB - Bogor \\ 3;4Pembimbing 2 \& 3 dan Dosen Prodi IImu Faal dan Khasial Obat IPB - Bogor \\ *Email korespondensi :
}

(Submit 15/03/2019, Revisi 05/09/2019, Diterima 20/12/2019)

\begin{abstract}
Abstrak
Telah dilakukan penelitian dalam rangka inovasi produk hand rub alcohol base. Hand rub adalah sediaan antiseptik yang digunakan untuk membersihkan tangan tanpa menggunakan air. Formula yang digunakan dalam penelitian ini adalah kombinasi Etanol 96\%; $\mathrm{H}_{2} \mathrm{O}_{2} 3 \%$; Gliserol 98\% ; Aqua Steril ad. total volume. Tujuan penelitian ini untuk menciptakan sediaan hand rub alcohol base yang bermutu dan terjangkau (efisien) dibandingkan dengan produk pabrikan yang ada di Indonesia. Metode yang digunakan dengan hand rub dibuat dalam prosedur bersih, dalam sediaan akhir 500 $\mathrm{mL}$. kadar akhir kandungan alcohol sediaan hand rub harus minimal $>80 \%$. Untuk mengetahui mutu sediaan handrub dilakukan dengan uji percentage kill, dengan menggunakan sampel bakteri : Escherichia Coli; Staphylococcus epidermidis; Pseudomonas aeruginosa; Methicillin resistance staphylococcus aureus (MRSA). Pembuatan produk hand rub dilakukan di Instalasi Farmasi RSUP Fatmawati; pengujian percentage kill dilakukan di Laboratorium mikrobiologi Universitas Indonesia (UI) Jakarta. Berdasarkan hasil uji percentage kill diketahui bahwa pada menit kontak ke 1;2 dan 5, untuk bakteri Escherichia Coli diketahui mengalami eradikasi 99,90\%. Begitu juga untuk Staphylococcus epidermidis, diketahui untuk waktu kontak pada menit ke 1;2 dan 5, nilai percentage kill adalah 99,90\%. Untuk bakteri Pseudomonas aeruginosa diketahui pada waktu kontak menit ke 1;2 dan 5, nilai percentage kill adalah 99,90\%. Sama halnya dengan bakteri MRSA, diketahui pada waktu kontak menit ke 1;2 dan 5, nilai percentage kill adalah 99,90\%. Hal ini menunjukkan bahwa hasil kualitas produk hand rub adalah baik, karena berdasarkan hasil Uji percentage kill diperoleh nilai untuk tiap waktu kontak $\geq 90 \%$. Nilai Efisiensi_diketahui, harga produk hand rub alcohol base dengan kadar akhir alcohol >80\%. Di e-catalogue LKPP tahun 2018 sebesar Rp.78.750/botol $500 \mathrm{~mL}$. Diketahui untuk biaya yang dihabiskan dalam pembuatan sediaan hand rub inovasi produk ini sebesar Rp.30.500/botol $500 \mathrm{~mL}$. Untuk selama periode tahun 2018, hand rub yang digunakan di RSUP Fatmawati sebanyak 15.600 botol $500 \mathrm{~mL}$, dengan rata-rata penggunaan tiap bulan adalah 1.300/botol $500 \mathrm{~mL}$. Sehingga dengan diimplementasikannya produk ini di RSUP Fatmawati Jakarta maka nilai efisiensi yang diperoleh selama tahun 2018 adalah Rp.752.700.000 (tujuh ratus lima puluh dua juta tujuh ratus ribu rupiah).
\end{abstract}

Kata kunci: hand rub, alcohol base, IFO, fatmawati, percentage kill, efisiensi 


\section{Outline}

- Pendahuluan

- Metode

- Hasil dan Pembahasan

- Kesimpulan

- Daftar Pustaka

\section{Pendahuluan}

Penyakit infeksi masih menjadi salah satu masalah kesehatan di dunia, termasuk Indonesia. Penyakit infeksi ditinjau dari asal atau didapatnya infeksi dapat berasal dari komunitas (Community Acquired Infection) atau berasal dari lingkungan rumah sakit (Hospital Acquired Infection) yang sebelumnya dikenal dengan istilah infeksi nosokomial ${ }^{1}$.

Menurut WHO (2015), Penyakit infeksi saat ini menjadi ancaman serius bagi umat manusia. Hal ini sejalan dengan semakin meningkatnya resistensi antibiotik, bahkan kasus tersebut mengarah ke tingkat yang sangat tinggi di semua belahan dunia. Mekanisme resistensi baru selalu muncul dan menyebar secara global setiap hari, mengancam kemampuan manusia untuk mengobati penyakit menular yang umum. Peningkatan kasus resistensi tersebut terjadi pada beberapa kasus seperti infeksi darah, pneumonia, tuberkulosis, dan gonore, sehingga menjadikannya sulit atau bahkan kadang - kadang tidak mungkin untuk dapat disembuhkan, dan hal ini menyebabkan sebagai besar antibiotik menjadi kurang efektif.

Menurut laporan dari WHO's new Global Antimicrobial Surveillance System (GLASS) mengungkapkan terjadinya resistensi antibiotik secara luas diantara 500.000 orang yang diduga terinfeksi bakteri di 22 negara. Bakteri resisten yang paling sering dilaporkan adalah Escherichia coli, Klebsiella pneumoniae, Staphylococcus aureus, dan Streptococcus pneumoniae. Kemudian diantara pasien dengan dugaan infeksi aliran darah, proporsi bakteri yang resisten terhadap paling sedikit satu antibiotik yang paling banyak digunakan di berbagai negara yaitu $0-82 \%{ }^{3}$.

Menurut WHO (2009) kejadian Infeksi di fasilitas pelayanan kesehatan dapat terjadi karena disebabkan oleh banyak faktor yang berbeda. Hal ini dapat terkait langsung dengan sistem dan proses penyediaan perawatan serta perilaku manusia, tingkat pendidikan, kendala politik dan ekonomi pada sistem dalam suatu negara, dan sering pula terkait dengan norma dan keyakinan masyarakat. Padahal sebagian besar kejadian infeksi, secara umum dapat dicegah. Dimana Kebersihan tangan adalah ukuran utama untuk mengurangi infeksi tersebut. Tindakan ini mungkin terlihat sederhana, tetapi faktanya, akibat kurangnya kepatuhan pada kebersihan tangan petugas di penyedia layanan kesehatan, dapat memicu permasalahan di seluruh dunia. Berdasarkan hasil penelitian tentang aspek mempengaruhi terhadap kepatuhan menjaga kebersihan tangan dan strategi edukasinya, yang merupakan sebuah pendekatan baru telah terbukti efektif dalam mencegah kejadian infeksi dirumah sakit. Berbagai strategi untuk promosi dan perbaikan dalam menjaga kebersihan tangan petugas kesehatan telah diupayakan, pada tema pertama Tantangan Keselamatan Pasien Global WHO, "Clean Care is Safer Care", yang menjadikan sebagian perhatian pada peningkatan standar dan praktik kebersihan tangan dalam perawatan kesehatan 
bersama di dunia ${ }^{2}$.

Transmisi (penularan) patogen pada perawatan kesehatan dapat terjadi melalui: kontak langsung dan tidak langsung, droplet, udara yang terkontaminasi. Transmisi melalui tangan yang terkontaminasi adalah pola yang paling umum di sebagian besar pelayanan kesehatan. Untuk itu WHO (2009) mencanangkan 5 (lima) keadaan yang mewajibkan petugas kesehatan untuk mencuci tangan, yaitu: (i) setelah melakukan kontak dengan pasien : karena organisme yang ada di kulit pasien dapat berpindah ke tangan petugas saat terjadi kontak; (ii) setelah terkena cairan tubuh: organisme pathogen pada cairan tubuh dapat mengkontaminasi tangan petugas, sehingga dapat bertransmisi pada pasien atau sebaliknya; (iii) setelah kontak dengan lingkungan perawatn pasien: hal ini dilakukan karena lingkungan pasien kemungkinan telah terjadi cemaran berasal dari droplet atau cairan tubuh pasien; (iv) sebelum kontak dengan pasien: untuk mencegah transmisi pathogen dari tangan petugas pada pasien; ( $v$ ) sebelum melakukan tindakan steril: organisme pathogen mampu bertahan setidaknya selama beberapa menit di tangan petugas, sehingga sebelum melakukan tindakan steril harus melakukan handrub.

\section{Antiseptik Tangan}

Antiseptik tangan dengan basis alkohol paling sering mengandung etanol, isopropanol atau n-propanol, atau kombinasi dua dari jenis tersebut ${ }^{2}$.

$$
\mathrm{CH}_{3} \mathrm{CH}_{2} \mathrm{OH}
$$

Pada umumnya, isopropanol memiliki efikasi terhadap bakteri lebih besar ${ }^{4}$ dan etanol lebih poten terhadap virus, namun hal tersebut juga tergantung dari konsentrasi kedua zat aktif tersebut dan uji mikroorganisme. Sebagai contoh, isopropanol memiliki sifat lebih lipofil dibandingkan etanol dan memiliki aktifitas yang kecil terhadap virus hidrofil (contoh polivirus) ${ }^{5}$.

Larutan alkohol yang mengandung $60-80 \%$ alkohol adalah paling efektif, dengan semakin besar konsentrasi potensinya semakin kecil. Masih sedikit bagaimana secara spesifik model dari mekanisme alkohol, namun berdasarkan peningkatan efikasi terhadap adanya air, secara umum bahwa alkohol menyebkan kerusakan membrane dan denaturasi protein, dengan selanjutnya menyebabkan ganguan metabolism dan lisis protein ${ }^{6}$.

Alkohol memiliki aktifitas germisidal yang sangat baik secara in vitro terhadap gram positif dan bakteri vegetative gram negatif (termasuk multidrug-resistant pathogen seperti MRSA dan VRE), M. tuberculosis, dan varietas dari jamur. Meskipun demikian, alkohol secara virtual tidak memiliki aktifitas terhadap spora bakteri atau protozoanoocyt, dan memiliki aktifitas yang buruk terhadap beberapa virus nonenveloped (non-lipholic). Beberapa virus enveloped (lipophilic) seperti virus hepes simplex (HSV), HIV. Virus influenza, RSV, dan virus vaccinia sensitif terhadap alkohol ketika diuji secara in vitro. Virus enveloped lainnya yang kurang sensitif terhadap alkohol, namun terbuhun oleh alkohol $60-70 \%$ antara lain termasuk virus hepatitis B (HBV) dan dimungkinkan juga virus hepatitis $\mathrm{C}$. Pada sebuah model pembawa jaringan porcine yang digunakan untuk mempelajari aktivitas antiseptik, etanol $70 \%$ dan isopropanol $70 \%$ ditemukan dapat mengurangi titre dari bakteriofag enveloped lebih efektif ddibandingkan dengan sabun antibakteri mengandung $\mathrm{CHG} \mathrm{4 \%}$ ? 
Alkohol dengan cepat membunuh bakteri saat diaplikasikan pada kulit, tidak memiliki aktivitas persisten (sisa). Namun, pertumbuhan kembali bakteri pada kulit terjadi secara perlahan setelah penggunaan antiseptic berbasis alkohol. Hal ini dimungkinkan karena efek sub-letal alkohol terhadap beberapa bakteri kulit ${ }^{2}$.

Sejumlah penelitian telah mendokumentasikan aktivitas antimikroba alkohol secara in vivo. Studi kuantitatif awal dari efek antiseptik handrub menetapkan bahwa alkohol secara efektif mengurangi jumlah bakteri di tangan. Biasanya, pengurangan log pelepasan bakteri uji dari tangan terkontaminasi secara artifisial rata-rata $3.5 \log _{10}$ setelah 30 menit aplikasi, dan 4.0-5.0 $\log _{10}$ setelah 1 menit aplikasi ${ }^{2}$.

\section{Metode}

\section{A. Metode Pembuatan}

1. Formula Handrub

Perbandingan standar formula handrub yang dikeluarkan oleh WHO (2009), dengan modifikasi formula untuk volume total 10 liter, dengan perbandingan sebagai berikut,:

Tabel 1. Perbandingan Formula WHO dan Modifikasi Formula Handrub dalam volume total $10 \mathrm{~mL}$

\begin{tabular}{|c|c|c|}
\hline & rub Formula WHO & Handrub Modifikasi Formula \\
\hline " & Etanol 96\% = $8333 \mathrm{ml}$ & Etanol $96 \%=8780 \mathrm{ml}$ \\
\hline " & $\mathrm{H}_{2} \mathrm{O}_{2} 3 \%=417 \mathrm{ml}$ & $\mathrm{H}_{2} \mathrm{O}_{2} 3 \%=100 \mathrm{ml}$ \\
\hline " & Gliserol 98\% = $145 \mathrm{ml}$ & Gliserol 98\% = $5 \mathrm{ml}$ \\
\hline - & $\begin{array}{l}\text { Aquades steril atau } \\
\text { air dingin }\end{array}$ & $\begin{array}{l}\text { - Aquades steril atau } \\
\text { air dingin }\end{array}$ \\
\hline & $\begin{array}{l}\text { yang telah didihkan } \\
\text { ad } 10 \text { liter }\end{array}$ & $\begin{array}{l}\text { yang telah didihkan ad } \\
10 \text { liter }\end{array}$ \\
\hline
\end{tabular}

\section{Peralatan yang Digunakan}

Di bawah ini merupakan peralatan yang digunakan pada produksi handrub sebanyak 10 liter.

- Jerigen, tangki tertutup untuk kapasitas 20 liter

- Gelas ukur $500 \mathrm{ml}$

- Labu takar 5 liter

- Botol pengemasan ukuran $500 \mathrm{ml}$

\section{Tahapan Pembuatan}

Berikut ini merupakan prosedur pembuatan handrub, untuk volume total 10 liter:

1) Tahap persiapan pembuatan

a) Siapkan alat dan bahan yang digunakan untuk proses produksi handrub.

b) Pencatatan dalam dokumen produksi tentang seluruh kegiatan produksi pembuatan handrub.

c) Pembuatan etiket/ stiker botol pengemasan dengan menuliskan tanggal produksi, nomor batch, dan "sebaiknya digunakan sebelum tanggal".

2) Pelaksanaan proses pembuatan
a) Masukan alkohol $96 \%$ ke dalam wadah tertutup rapat (tangki/ jerigen penampung) sebanyak $8780 \mathrm{ml}$.
b) Tambahkan $\mathrm{H}_{2} \mathrm{O}_{2} 3 \%$ dengan menggunakan gelas ukur sebanyak $100 \mathrm{ml}$.
c) Tambahkan gliserol $98 \%$ dengan menggunkan gelas ukur sebanyak $5 \mathrm{ml}$. 
d) Bilas sisa gliserol dalam gelas ukur hinga bersih dengan aquadest steril.

e) Ukur kadar alkohol dengan alkohol meter; kadar akhir $>80 \%$

f) Tutup rangka tangki/ jerigen penampung untuk mencegah penguapan.

g) Goyang/ kocok tangki atau jerigen penampung selama 10 menit supaya cairan tercampur secara merata.

h) Tuang segera dalam botol pengemas $500 \mathrm{~mL}$ dan tutup rapat.
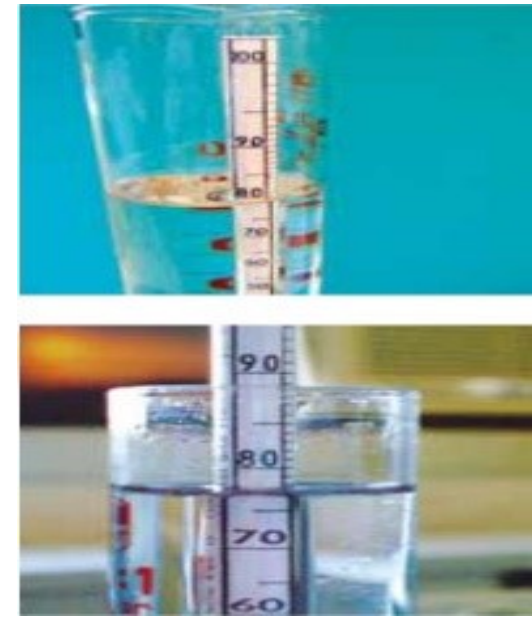

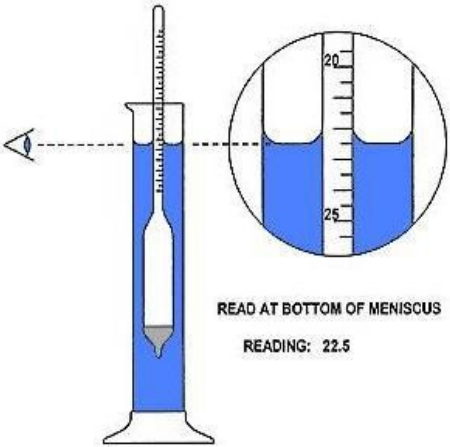

Gambar 1.

3) Pelaksanaan penyimpanan

a) Tempatkan dalam rak/ lemari penyimpan.

b) Diamkan selama 72 jam dalam suhu ruangan.

c) Berikan penanda "dalam masa simpan, belum dapat digunkan".

d) Ukur kadar alkohol setelah penyimpanan 72 jam dengan alkohol meter; kadar akhir alcohol tidak boleh kurang dari $>80 \%$

\section{B. Metode Pengujian}

Setiap formulasi baru untuk antisepsis tangan harus diuji mutu antimikroba bersama dengan semua bahan tambahannya untuk memastikan bahwa setiap eksipien ditambahkan untuk toleransi kulit yang lebih baik tidak mempengaruhi aktivitasnya. Pengujian yang mungkin dapat dilakukan untuk mendapatkan aktivitas antimikroba dari handrub termasuk in vitro test, seperti penentuan konsentrasi minimal bakterisida (Minimal Bactericidal Concentration), kill-curves dan uji kuantitatif suspense, atau dengan protocol ex vivo menggunakan eksplan hewan atau kulit manusia. Kondisi pada suspense dan uji in vitro atau ex vivo tidak dapat mencerminkan kulit manusia. Bahkan tes simulasi dengan subjek dianggap oleh beberapa orang sebagai "terlalu dikontrol", yang mendorong pengujian di bawah praxi atau kondisi lapangan. Pengujian lapangan seperti itu sulit dikendalikan terhadap faktor asing. Selain itu, dan yang terpenting, temuan-temuan dari uji lapangan memberikan sedikit data tentang kemampuan formulasi yang diberikan untuk menyebabkan pengurangan yang terukur dalam infeksiinfeksi nosokomial yang ditularkan melalui tangan ${ }^{2}$.

Pengujian time-kill merupakan metode dalam menentukan efektivitas antimikroba (handrub) dengan teknik plate count dan analisis dari persen dan log reduksi ${ }^{7}$. Prosedur yang dilakukan dalam pengujian ini adalah mengikuti standar dari ASTM (Antimicrobila Susceptibility Testing Method) E-2313. Setelah dilakukan persiapan kultur bakteri, tempatkan sejumlah sampel uji yang cukup untuk kegiatan pengujian kedalam 
cawan petri steril. Kemudian sejumlah kultur bakteri yang akan diuji (biasanya 1/10 atau kurang dari volume sampel uji) diinokulasi ke dalam cawan petri sebelumnya dan kemudian segera diaduk. Setelah waktu kontak yang telah ditentukan, sejumlah kecil dari campuran bakteri dan sampel uji diambil, dan dimasukkan ke dalam cawan berisi agar nutrisi, dan kemudian diinkubasi pada suhu 37 selama 24 jam ${ }^{7}$. Adapun rumus untuk menghitung reduksi log 7 .

\section{Hasil dan Pembahasan}

\section{A. Hasil Pengujian percentage kill}

Berdasarkan hasil uji percentage kill diketahui bahwa pada menit kontak ke 1;2 dan 5, untuk bakteri Escherichia Coli diketahui mengalami eradikasi 99,90\%. Begitu juga untuk Staphylococcus epidermidis, diketahui untuk waktu kontak pada menit ke 1;2 dan 5, nilai percentage kill adalah 99,90\%. Untuk bakteri Pseudomonas aeruginosa diketahui pada waktu kontak menit ke 1;2 dan 5, nilai percentage kill adalah 99,90\%. Sama halnya dengan bakteri MRSA, diketahui pada waktu kontak menit ke 1;2 dan 5 , nilai percentage kill adalah $99,90 \%$.

Tabel 2. Hasil Pemeriksaan

\begin{tabular}{|c|l|c|c|c|c|}
\hline No. & \multicolumn{1}{|c|}{ Jenis Bakteri } & \multicolumn{3}{c|}{ Waktu Kontak } & Keterangan \\
\hline 1 & Escherichia Coli & $99,90 \%$ & $99,90 \%$ & $99,90 \%$ & Baik; $\geq 90 \%$. \\
\hline $\mathbf{2}$ & Staphylococcus epidermidis & $99,90 \%$ & $99,90 \%$ & $99,90 \%$ & Baik; $\geq 90 \%$. \\
\hline 3 & Pseudomonas aeruginosa & $99,90 \%$ & $99,90 \%$ & $99,90 \%$ & Baik; $\geq 90 \%$. \\
\hline 4 & $\begin{array}{l}\text { Methicillin-resistant } \\
\text { staphylococcus aureus (MRSA) }\end{array}$ & $99,90 \%$ & $99,90 \%$ & $99,90 \%$ & Baik; $\geq 90 \%$. \\
\hline
\end{tabular}

Hal ini menunjukkan bahwa hasil kualitas produk hand rub adalah baik, karena berdasarkan hasil Uji percentage kill diperoleh nilai untuk tiap waktu kontak $\geq 90 \%$. Handrub yang diujikan tersebut merupakan preparat mengandung alkohol yang dirancang untuk aplikasi ke tangan untuk mengurangi jumlah mikroorganisme patogen. Alkohol merupakan komponen utama antibakteri yang digunakan pada sebagian besar agen antiseptik tanpa air. Handrub berbasis alkohol efektif terhadap bakteri gram positif dan gram negative, patogen multi-resiten, jamur dan virus ${ }^{2}$.

Handrub dapat mengatasi hambatan dan kepatuhan kebersihan karena membutuhkan waktu yang sedikit dalam mencuci tangan yang ekeftif, lebih kurang merusak kulit daripada sabun dan air dan lebih efektif dalam membunuh banyak mikroorganisme. Pada formulasi pembuatan handrub jenis alkohol yang digunakan adalah etanol, isopropanol atau n-propanol, atau kombinasi keduannya. Adapun zat tambahan yang digunakan adalah antara lain pengental (seperti asam poliakrilik untuk gel), humektan (seperti gliserin untuk cairan handrub) atau propilen glikol dan minyak esensial dari tanaman. Setiap formulasi dari handrub tersebut harus dilakukan uji mutu terhadap antimikroba. Hal ini bertujuan agar memastikan apakah efikasinya lebih dari pada sabun biasa atau apakah formulasi dengan zat tambahan yang ditambahkan untuk meningkatkan toleransi terhadap kulit tidak mempengaruhi afek antimikroba dari handrub ${ }^{2}$.

\section{B. Nilai Efisiensi}

Diketahui, harga produk hand rub alcohol base dengan kadar akhir alcohol $>80 \%$. Di ecatalogue LKPP tahun 2018 sebesar Rp.78.750/botol 500 mL. Diketahui untuk biaya 
yang dihabiskan dalam pembuatan sediaan hand rub inovasi produk ini sebesar Rp.30.500/botol $500 \mathrm{~mL}$. Untuk selama periode tahun 2018, hand rub yang digunakan di RSUP Fatmawati sebanyak 15.600 botol $500 \mathrm{~mL}$, dengan rata-rata penggunaan tiap bulan adalah $1.300 /$ botol $500 \mathrm{~mL}$. Sehingga dengan diimplementasikannya produk ini di RSUP Fatmawati Jakarta maka nilai efisiensi yang diperoleh selama tahun 2018 adalah Rp.752.700.000 (tujuh ratus lima puluh dua juta tujuh ratus ribu rupiah).

\section{Kesimpulan}

(tambahkan kesimpulan)

\section{Daftar Pustaka}

1. Kemenkes RI., 2011, Pedoman Pencegahan dan Pengendalian Infeksi di Rumah Sakit dan Fasilitas Pelayanan Kesehatan Lainnya, Cetakan ketiga, Kemenkes RI., Jakarta.

2. World Health Organisation., 2009. WHO guidelines in hand hygiene in health care. WHO/IER/PSP/2009.07, World Health Organisation, Geneva, Switzerland. 2009

3. World Health Organization., 2018. High Levels of Antibiotic Resistance Found Worldwide, New Data Shows. Media Centre : News Release. Diakses dari http://www.who.int/mediacentre/news/releases/2018/antibiotic-resistancefound/en/ pada tanggal 18 Maret 2018 pukul 19.00 WIB.

4. Coulthard, C. E., and G. Skyes., 1936. Germicidal effect of alcohol. Pharm. J. 137:79-81

5. Klein, M., and A. Deforest., 1983. Principles of viral inactivation, p. $422 \pm 434$. In S. S. Block (ed.), Disinfection, sterilization and preservation, 3rd ed. Lea \& Febiger, Philadelphia, Pa.

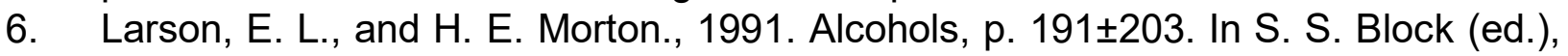
Disinfection, sterilization, and preservation, 4th ed. Lea \& Febiger, Philadelphia, Pa.

7. Oladosu, P., Isu, N.R., Ibrahim, K., Okolo, P., Oladepo, D.K., 2013. Time killkinetics antibacterial study of Acacia nilotica. African Journal of Microbiology Research, 7(46): 5248-5252.

8. Nester, E.W., Anderson, D.G., Roberts, C.E. and Nester, M.T., 2009. Microbiology: a Human Perspective, 6th edition. The McGraw-Hill Companies, Inc., New York. pp 480-481.

9. Osma S, Kahveci SF, Kaya FN, Akalin H, Ozakin C, Yilmaz E, et al., 2006. Efficacy of antiseptic-impregnated catheters on catheter colonization and catheterrelated bloodstream infections in patients in an intensive care unit. $J$ Hosp Infect 2006;62:156-62. http://dx.doi.org/10.1016/j.jhin.2005.06.030

10. Quinn PJ, Markey BK, Carter ME, Donelly WJ, Leonard FC., 2002. Veterinary Microbiology and Microbial Disease. lowa: Blackwell Publishing. 